\title{
Evaluation of Block Shear Properties of Selected Extreme-pH Structural Adhesives by Short-Term Exposure Test
}

\author{
Yaolin Zhang, ${ }^{1}$ Xiang-Ming Wang, ${ }^{1}$ Romulo Casilla, ${ }^{2}$ Paul Cooper, ${ }^{3}$ Zeen Huang, ${ }^{3}$ \\ Xiaodong Wang ${ }^{4}$ \\ ${ }^{1}$ FPInnovations-Wood Products, Quebec City, Quebec, Canada \\ ${ }^{2}$ FPInnovations-Wood Products, Vancouver, British Columbia, Canada \\ ${ }^{3}$ Faculty of Forestry, University of Toronto, Toronto, Ontario, Canada \\ ${ }^{4}$ Canadian Wood Fibre Centre, Laurentian Forestry Centre, Canadian Forest Service, Quebec City, Quebec, Canada
}

Received 15 June 2010; accepted 16 August 2010

DOI 10.1002/app.33210

Published online 21 October 2010 in Wiley Online Library (wileyonlinelibrary.com).

\begin{abstract}
Nine structural adhesives with varying $\mathrm{pH}$ were selected to examine the effect of adhesive $\mathrm{pH}$ on wood-adhesive bond quality. The adhesives evaluated included four highly alkaline phenol-formaldehyde, one intermediate $\mathrm{pH}$ phenol-resorcinol-formaldehyde, two acidic melamine-urea-formaldehyde, and two acidic melamine-formaldehyde resins. Block shear specimens were prepared using Douglas-fir and black spruce wood. The adhesive performance was evaluated by measuring the shear properties (strength and wood failure) of the specimens tested at the dry and vacuum-pressure-redry (VPD) conditions. Adhesive $\mathrm{pH}$, test condition, and wood species showed significant effects on shear properties. The different adhesives performed differently at the dry and VPD conditions. The high-pH adhesives (phenol-formaldehyde
\end{abstract}

and phenol-resorcinol-formaldehyde) showed similar high wood failures at both test conditions and performed better than the low-pH adhesives (melamine-formaldehyde and melamine-urea-formaldehyde), especially after the VPD conditioning. The low-pH adhesives showed high wood failure at the dry condition, but wood failure decreased significantly after VPD conditioning for both species, indicating that the low-pH adhesives were less durable than the high-pH adhesives. High-pH adhesives did not have a negative impact on the strength of the bonded specimens. (C) 2010 Wiley Periodicals, Inc. J Appl Polym Sci 120: 657-665, 2011

Key words: adhesives; failure; water-soluble polymers; thermosets; strength

\section{INTRODUCTION}

There are three types of linkages involved in a wood-adhesive bond, namely adhesive layer, woodadhesive interface, and wood layer adjacent to the adhesive layer. The latter is probably more susceptible to the negative effects of extreme $\mathrm{pH}$ for longterm exposure. The wood substance in wood cell walls is composed of holocellulose $(40-44 \%$ cellulose and $15-35 \%$ hemicellulose) and $18-35 \%$ lignin. Usually, a low $\mathrm{pH}$ predominantly affects the holocellulose, whereas a high $\mathrm{pH}$ mainly affects the lignin. ${ }^{1,2}$ Thus, a low pH may have a more detrimental effect on wood strength than a high $\mathrm{pH}$.

Gillespie and River ${ }^{3}$ reported that yellow birch and Douglas-fir plywood shear specimens stored for 4 years at $27^{\circ} \mathrm{C}$ and $30 \%$ relative humidity ( $\mathrm{RH}$ ) lost little, if any, strength when bonded with nonacidic

\footnotetext{
Correspondence to: Y. Zhang (Yaolin.Zhang@ fpinnovations.ca).

Contract grant sponsor: Natural Resources CanadaCanadian Forest Services.
}

Journal of Applied Polymer Science, Vol. 120, 657-665 (2011) (c) 2010 Wiley Periodicals, Inc. adhesives, but showed appreciable strength loss when bonded with acidic adhesives. Similarly, in an evaluation of the durability of various structural wood adhesives by indoor and roofed outdoor exposure, Raknes ${ }^{4,5}$ reported that acidic phenol-formaldehyde (PF) adhesives started showing signs of failure after 10-15 years, probably due to acid damage to the wood. In comparison, alkali resorcinol-formaldehyde (RF) adhesives still retained satisfactory strength.

Some adhesives become more acidic during curing. The acid-induced gelling reactions can cause severe deterioration of the wood substance. ${ }^{6}$ Kline et al. $^{7}$ observed strength losses in plywood with aging at $\mathrm{pH}$ values less than about 4 for urea-formaldehyde adhesives and 3.5 for PF adhesives. Wangaard $^{8}$ also found that with acid-catalyzed intermediate-temperature-setting $\mathrm{PF}$ at moderate humidity exposure conditions, the more acidic adhesives seemed to cause deterioration of the wood adjacent to the bond line. The alkaline-catalyzed adhesives did not show this effect. Similar observations were made by Eickner ${ }^{9}$ on bonding compreg-to-compreg with three types of adhesives (alkaline intermediatetemperature-setting $\mathrm{PF}$, room-temperature-setting $\mathrm{RF}$, and acidic $\mathrm{PF}$ ) exposed to $93^{\circ} \mathrm{C}$ and $20 \% \mathrm{RH}$. 
The author found that the alkaline intermediate-temperature-setting PF and the room-temperature-setting RF retained relatively high strengths after 1 year of exposure, whereas those glued with the acidic PF lost strength. Moreover, a Weyerhaeuser application guide on Microllam ${ }^{\circledR}$ laminated veneer lumber (LVL) scaffold plank ${ }^{10}$ indicates that the most hazardous acidic chemical solutions to wood are those that have $\mathrm{pH} \leq 3$.

Green et al. ${ }^{11}$ studied the durability of structural solid-sawn lumber (Douglas-fir, southern pine, spruce-pine-fir, and yellow poplar), LVL (Douglasfir, southern pine, and yellow poplar) bonded with $\mathrm{PF}$, and laminated strand lumber (LSL) (aspen and yellow poplar) with an isocyanate-based adhesive exposed at $82^{\circ} \mathrm{C}$ and $80 \% \mathrm{RH}$ for up to 24 months. After exposure, the products were reconditioned to room temperature at $25 \% \mathrm{RH}$ before testing in edgewise bending. Reductions in bending strength were observed for all three types of products after 12-24 months of exposure. They concluded that acid hydrolysis of hemicellulose, especially of arabinose, seemed to be the fundamental cause of strength loss resulting from thermal degradation. The products became more acidic with exposure time, and arabinose showed the largest and most consistent decrease with time of exposure. The average $\mathrm{pH}$ of the solid wood control dropped from 4.2 (unexposed) to 3.6 for specimens exposed to the above environment for 12-24 months; the average $\mathrm{pH}$ of the LVL dropped from 6.2 to 4.7 after 12 months, and the $\mathrm{pH}$ of LSL dropped from 4.8 to 3.8. The difference in $\mathrm{pH}$ between the LVL and LSL was probably due to the type of adhesive used in the products, where the PF used in LVL had higher $\mathrm{pH}$ than the isocyanate adhesive used in LSL.

Kline et al. $^{7}$ observed a correlation between strength loss on aging of plywood bonded with alkali-catalyzed PF and the increase in alkalinity of the panel and found that the critical plywood $\mathrm{pH}$ value above which deterioration on aging became appreciable was around 8 for PF adhesives. Blomquist ${ }^{12}$ investigated the effect of varying the alkalinity of a hot-pressed PF (film pH 10.0-11.5), an intermediatetemperature-setting PF (freshly mixed $\mathrm{pH}$ 8.0-10.2 and corresponding film $\mathrm{pH} 8.1-11.2$ ), and a roomtemperature-setting RF (freshly mixed $\mathrm{pH}$ 7.1-8.4 and corresponding film $\mathrm{pH}$ 7.4-8.8), by varying the amount of caustic soda added to the adhesive formulation, on the wood-adhesive bond in yellow birch and Douglas-fir plywood specimens. The specimens were exposed continuously at different conditions (about $27^{\circ} \mathrm{C} / 65 \% \mathrm{RH}, 70^{\circ} \mathrm{C} / 20 \% \mathrm{RH}$, about $27^{\circ} \mathrm{C} /$ $97 \% \mathrm{RH})$, or repeated cyclic high and low humidity (2 weeks at $27^{\circ} \mathrm{C} / 97 \% \mathrm{RH}$ followed by 2 weeks at $\left.27^{\circ} \mathrm{C} / 30 \% \mathrm{RH}\right)$, over a 2- to 3-year period. Exposure at room conditions had no significant effect on the durability of the specimens regardless of the alkalinity of the adhesive formulations. Exposure at elevated temperature/low humidity for 3 years showed evidence of damage to the wood in birch specimens bonded with the most alkaline hot-pressed PF formulations when tested wet. Exposure at high humidity/ room temperature was found to be the most damaging condition to the most alkaline hot-pressed PF used in the tests. Exposure at the cyclic high/low humidity for 3 years resulted in significant losses in strength and wood failure in birch plywood bonded with the two most alkaline hot-pressed PF.

$\mathrm{Hse}^{13}$ examined the effects of several PF adhesive properties, including $\mathrm{pH}$, on the bond quality of southern pine plywood. The $\mathrm{pH}$ of the liquid adhesive ranged from 10.5 to 12.1 . However, the corresponding cured adhesive film $\mathrm{pH}$ would likely be higher based on the observations by Blomquist ${ }^{12}$ and Kline et $\mathrm{al}^{7}$ The relationships of $\mathrm{pH}$ to wet shear strength and wood failure were found to be parabolic. It is interesting to note that from the regression equations generated, the maximum values of wood failure and shear strength were found to correspond to liquid adhesive $\mathrm{pH} 11.0$ and $\mathrm{pH}$ 10.7, respectively. The author indicated that it was unlikely that $\mathrm{pH}$ altered the wood substrate sufficiently to influence the quality of bonding. Santos et al. ${ }^{14}$ examined the effects of $\mathrm{pH}$ and synthesis temperature on the performance of thermosetting adhesive formulations based on demethylated wood creosote-formaldehyde when used in bonding Araucaria angustifolia sheets. The $\mathrm{pH}$ 's of the adhesive formulations were 12.00, 12.25, 12.50, 12.75, 13.00, 13.25 , and 13.50. The dry and wet shear strengths were observed to be positively and linearly correlated with increasing $\mathrm{pH}$. However, no trend was observed between $\mathrm{pH}$ and wood failure. These results indicated that within the $\mathrm{pH}$ range studied, the adhesive probably did not have an adverse effect on the wood. Zimmermann et al. ${ }^{15}$ showed that 5-hr exposure of spruce wood to $10 \% \mathrm{NaOH}, 18 \% \mathrm{NaOH}$, or $24 \% \mathrm{KOH}$ at room temperature resulted in slight reductions in hemicellulose components and, in most cases, significant reductions in bending strength and stiffness.

This project was conducted to better understand the role and need for $\mathrm{pH}$ limits on the cured adhesive film with respect to the development of adhesive standards that ensure good long-term performance and, at the same time, permit innovative adhesive systems to be developed and used in the most appropriate applications. The goal of this study was to provide background information that will assist wood adhesive standard committees in refining the newly published CSA O112.9 $9^{16}$ and O112.10 17 standards. The main objective was to evaluate the effect of extreme $\mathrm{pH}$ of acidic and basic adhesives on bond durability and performance after exposure to different environmental conditions. The 
TABLE I

Wood Adhesives Used in the Study and $\mathrm{pH}$ of the Cured Adhesives

\begin{tabular}{|c|c|c|c|c|c|c|}
\hline \multirow[b]{2}{*}{ Resin ID } & \multirow[b]{2}{*}{ Resin type } & \multicolumn{4}{|c|}{$\mathrm{pH}$ of cured adhesive films ${ }^{\mathrm{a}}$} & \multirow[b]{2}{*}{ Remarks $^{b}$} \\
\hline & & Method 1 & Method 2 & Method 3 & Method 4 & \\
\hline R-I & PF & $12.79(0.04)$ & $13.15(0.05)$ & & $13.11(0.04)$ & $\mathrm{n} / \mathrm{a}$ \\
\hline R-II & $\mathrm{PF}$ & $12.76(0.05)$ & $12.81(0.07)$ & & $12.15(0.07)$ & $\mathrm{n} / \mathrm{a}$ \\
\hline R-III & PF & $12.44(0.04)$ & $12.87(0.09)$ & & $12.00(0.04)$ & $\mathrm{n} / \mathrm{a}$ \\
\hline R-IV & PF & $12.11(0.05)$ & $12.69(0.05)$ & & $11.95(0.08)$ & $\mathrm{n} / \mathrm{a}$ \\
\hline $\mathrm{R}-\mathrm{V}$ & PRF & $10.58(0.03)$ & $10.84(0.03)$ & $10.09(0.05)$ & $10.51(0.05)$ & $2.2: 1.0(6.0: 1.0)^{\mathrm{C}}$ \\
\hline R-VI & MUF & $2.92(0.07)$ & $6.91(0.09)$ & $2.94(0.05)$ & $4.98(0.02)$ & $100: 25$ \\
\hline R-VII & MUF & $2.78(0.11)$ & $7.00(0.50)$ & $2.78(0.11)$ & $4.99(0.06)$ & $100: 30$ \\
\hline R-XI & MF & $3.72(0.04)$ & $3.63(0.22)$ & $3.93(0.03)$ & $3.98(0.02)$ & $100: 10$ \\
\hline R-XII & $\mathrm{MF}$ & $3.60(0.03)$ & $2.39(0.06)$ & $3.71(0.01)$ & $3.84(0.01)$ & $100: 20$ \\
\hline
\end{tabular}

a The result is the average of three replicates, and the values in parentheses are standard deviations.

$\mathrm{b}$ The actual weight ratio of resin to hardener.

${ }^{c}$ The weight ratio of resin and hardener based on solids content. The values in parentheses are solids weight ratio of resin to hardener.

study examined the impact of wood species, highand low-pH adhesives, and exposure conditions on block shear properties (strength and wood failure).

\section{MATERIALS AND METHODS}

\section{Adhesives}

Four commercially used high-pH PF adhesives (R-I, R-II, R-III, and R-IV) and one intermediate $\mathrm{pH}$ phenol-resorcinol-formaldehyde (PRF) adhesive (R-V; liquid resin $\mathrm{pH}$ around 10.0) were supplied by adhesive manufacturers (Tembec [Elko, BC, Canada], Hexion [Quebec, QC, Canada], Arclin [Springfield, OR]). The hardener for $\mathrm{R}-\mathrm{V}$ was $20-25 \%$ powder slurry of which the major components were paraformaldehyde and walnut shell flour. In addition, one commercial low-pH melamine-urea-formaldehyde (MUF) adhesive was made into two different $\mathrm{pH}$ formulations (R-VI and R-VII) by adding different levels of hardener. The hardener was a slurry composed of several chemicals, mainly formic acid and resorcinol. The slurry had a $\mathrm{pH}$ of around 1.5, and its volatile content was about $40 \mathrm{wt} \%$. A commercial low-pH melamine-formaldehyde (MF) (methylated melamine) adhesive was also made into two different $\mathrm{pH}$ formulations ( $\mathrm{R}-\mathrm{XI}$ and $\mathrm{R}-\mathrm{XII}$ ) by varying the weight ratios of resin to hardener. The main component of the hardener was aluminum chloride, and the nonvolatile content was between 20 and 30 wt \%. For the MUF and MF, the ratios of resin to hardener were within the range recommended by the adhesive manufacturers. Information on the adhesives used in the study is given in Table I. The four high-pH PF adhesives, the intermediate $\mathrm{pH}$ PRF adhesive, and one of the low-pH MF adhesives have been certified and are currently used for engineering wood applications in North America. The low-pH MUF adhesive was used to be used for structural application, but it is no longer on the mar- ket. The manufacturer kindly prepared this type of MUF adhesive for this study.

\section{Wood substrate}

The wood species used were black spruce (Picea mariana [Mill.] BSP) supplied by a local sawmill (i.e., in Quebec) and Douglas-fir (Pseudotsuga menziesii [Mirb.] Franco) obtained from Tembec. They were stored at $65 \% \mathrm{RH}$ and temperature of $21^{\circ} \mathrm{C}$ for 6 months to reach equilibrium moisture content (EMC). The billets were cut with the following dimensions: black spruce, $820 \times$ $138 \times 31 \mathrm{~mm}$ (length $\times$ width $\times$ thickness) and Douglas-fir, 820 (or 600 ) $\times 88 \times 32 \mathrm{~mm}$. Only the billets that met the visual wood quality requirements of CSA O112.9 standard were selected. They were planed on both surfaces to about $21 \mathrm{~mm}$ in thickness, measured for weight and density, and stored at $65 \% \mathrm{RH} / 21^{\circ} \mathrm{C}$ before use in less than $24 \mathrm{hr}$. Densities of wood were measured before assembling by weighing the billets after conditioning and measuring the length, width, and thickness. The densities of the Douglas-fir billets selected were $0.65-0.75 \mathrm{~g} / \mathrm{cm}^{3}$ and those of black spruce were $0.45-0.55 \mathrm{~g} / \mathrm{cm}^{3}$ based on actual weight and volume at $65 \% \mathrm{RH}$ and $21^{\circ} \mathrm{C}$.

\section{Design of experiment}

Nine adhesives with different pHs, two wood species (Douglas-fir and black spruce), and two test conditions (dry and vacuum-pressure-redry [VPD]) were used. For each treatment combination, at least 20 block shear specimens were prepared. Block shear specimens of solid wood were also prepared as controls.

\section{Preparation of cured adhesive films and $\mathrm{pH}$ measurement}

Four methods were adopted to prepare cured adhesive films for $\mathrm{pH}$ measurement: Method 1, adhesives 
were cured at $102-105^{\circ} \mathrm{C}$ for $1 \mathrm{hr}$ based on CSA O112.6-1977 ${ }^{18}$ for hot-setting resins; Method 2, adhesives were cured at $66^{\circ} \mathrm{C}$ for $4 \mathrm{hr}$, followed by $1 \mathrm{hr}$ at $150^{\circ} \mathrm{C}$ based on ASTM D $1583-01^{19}$ for hot-setting resins; Method 3, adhesives were cured at room temperature overnight based on ASTM D 1583-01 for room-temperature-setting resins and or CSA O112.7" ${ }^{20}$; and Method 4, the cured resin squeezed out of glue lines during hot pressing was collected from block shear assemblies. Information on the $\mathrm{pH}$ of the cured films of the adhesives is given in Table I. More detailed information is available in the study of Zhang et al. ${ }^{21}$

\section{Block shear specimen preparation}

The preparation of two-ply test assemblies followed the procedures recommended by the adhesive manufacturers. The spread rates were different from resin to resin, ranging from 190 to $300 \mathrm{~g} / \mathrm{m}^{2}$. The open assembly time was 2-8 min and the closed assembly time was 10-20 min. The platen temperature was $150-180^{\circ} \mathrm{C}$, and the press time was $1-3$ min after the glue-line temperature reached $100^{\circ} \mathrm{C}$. The block shear assembly and shear specimens were prepared according to ASTM D 905-03. ${ }^{22}$ For comparison, solid wood block shear specimens were also prepared. To minimize the variability because of wood, the shear specimens cut from each assembly were assigned alternately to the two test conditions by sequence, i.e., the specimens were matched.

\section{Conditioning and testing}

Block shear specimens were conditioned by one of the two methods before test: dry and VPD. For the dry condition, the block shear specimens were conditioned at $65 \% \mathrm{RH}$ and $21^{\circ} \mathrm{C}$ to reach EMC of about $12 \%$. For the VPD condition, the specimens were placed in an impregnation tank, and a metal screen sheet placed over the specimens and weighted down. Tap water $\left(\sim 20^{\circ} \mathrm{C}\right)$ was introduced into the tank to immerse the specimens. A vacuum of 635 $\mathrm{mmHg}(85 \mathrm{kPa})$ was applied for $30 \mathrm{~min}$, followed by a pressure of $550 \mathrm{kPa}$ for $120 \mathrm{~min}$. After impregnation, the pressure was released, excess water was wiped from the specimen surfaces, and the specimens were then placed in an oven at $60^{\circ} \mathrm{C}$ to dry to their original weight. The redried specimens were conditioned at $65 \% \mathrm{RH}$ and $21^{\circ} \mathrm{C}$ to reach EMC prior to test.

The specimens were tested in shear by compression loading using a shear test device described in ASTM D 905-03. The load rate was $10 \mathrm{~mm} / \mathrm{min}$. After testing, the specimens were dried at $105^{\circ} \mathrm{C}$ for at least $24 \mathrm{hr}$ before MC measurement and wood fail- ure assessment. Wood failure was determined using guidelines described in ASTM D 5266. ${ }^{23}$

Moisture content (MC) of the specimens was determined by determining the weight of specimens before and after oven drying. The MC is calculated as weight difference before and after 24-hr oven-drying divided by oven-dry weight.

\section{Data analysis}

Statistical analyses were performed to examine the effects of the factors on the response variables. Analysis of covariance was also performed to examine the covariate impact on the response variables, and one-way fixed-effects treatment structure with simple linear regression models was used to make adjustments to the values. ${ }^{24}$ Analysis of variance (ANOVA) was also applied to examine the variance of a dependent variable. The ANOVA table shows the statistics used to test hypotheses about the population means, in which the mean squares are formed by dividing the sum of squares by the associated degrees of freedom. The $F$ value is the test statistic used to decide whether the sample means are within sampling variability of each other. The $P$ value indicates the probability of getting a mean difference between the groups as high as what is observed by chance.

\section{RESULTS AND DISCUSSION}

\section{The $\mathrm{pH}$ of cured films and squeezed-out cured} adhesives

\section{High-pH adhesives}

The $\mathrm{pH}$ values of the cured films of the high-pH adhesives took a few days to reach equilibrium. The $\mathrm{pH}$ values at the different curing conditions are summarized in Table I. Of the five adhesives, only $\mathrm{R}-\mathrm{V}$ could be cured at room temperature. The $\mathrm{pH}$ values of the cured films obtained with Method 2 were higher than those obtained with Method 1. This was probably attributed to the higher curing temperature used in the former method. The results obtained from Method 4 were also different from those obtained from Methods 1 and 2. This was probably due to the differences in the assembly procedures recommended by the adhesive manufactures. Curing conditions had a significant effect on $\mathrm{pH}$ (Table I). The $\mathrm{pH}$ obtained from Method 4 (i.e., using the squeezed-out adhesive from the glue line of the block shear assemblies) was different from that obtained from the adhesive in the glue line because the resin did not experience the same curing conditions. It should be pointed out that it was very difficult to collect a pure cured adhesive sample from the glue line without any wood component 
being attached because the glue line was very thin. However, the $\mathrm{pH}$ measured from Method 4 could provide a clue for estimating the $\mathrm{pH}$ of the glue line. The trend in $\mathrm{pH}$ of the cured films using Method 4 was estimated to be: R-I $>$ R-II $>$ R-III $\geq$ R-IV $>$ R$\mathrm{V}$, which varied from 13.11 to 10.51 .

\section{Low-pH adhesives}

The $\mathrm{pH}$ values of the cured films of the low-pH adhesives measured with the four methods also took a few days to stabilize. This indicates that the cured adhesives either underwent hydrolysis in the aqueous solution or the acid components in the ground particles took time to dissolve in the water. The $\mathrm{pH}$ values obtained at different curing conditions are summarized in Table I. The $\mathrm{pH}$ changed markedly with different curing conditions. For adhesives R-VI and R-VII, the pH increased from 2.92 to 6.91 and from 2.78 to 7.00 when measured with Methods 1 and 2, respectively. However, for R-XI and R-XII, the $\mathrm{pH}$ decreased from 3.72 to 3.63 and from 3.60 to 2.39 when measured with Methods 1 and 2, respectively. The $\mathrm{pH}$ of the cured films was lower than 3.0 when measured with Methods 1, 2, or 3 and was always higher than 3.0 (around 4 or 5) when measured with Method 4.

\section{Block shear properties}

Solid wood

The published shear strengths parallel to the grain of Douglas-fir and black spruce are shown in Table II. Table II shows that the specific gravity and shear strength of solid wood vary with the location of growth and MC. As indicated above, the wood samples used in this study were sourced in Canada. The density of the Douglas-fir used was $0.62-0.72 \mathrm{~g} / \mathrm{cm}^{3}$ based on actual weight at $\sim 12 \% \mathrm{MC}$ and volume at $\sim 12 \% \mathrm{MC}$, which would be equivalent to specific gravity of $0.54-0.64$ based on weight when oven dry and volume at $12 \% \mathrm{MC}$. This was higher than the published value, indicating the effect of growth location on this property. The density of the black spruce used was $0.50-0.56 \mathrm{~g} / \mathrm{cm}^{3}$ based on actual weight at $\sim 12 \% \mathrm{MC}$ and volume at $\sim 12 \% \mathrm{MC}$, which would be equivalent to specific gravity of $0.45-0.50$ based on weight when oven dry and volume at $12 \% \mathrm{MC}$. This was similar to the published value. Other factors that affect shear strength are test method and specimen type. ASTM D $2559^{26}$ indicates that bonded shear specimens tested in accordance with ASTM D 905-03, on the average, yield higher shear strength values than solid wood shear specimens tested in accordance with ASTM D $143 .^{27}$
TABLE II

Block Shear Strength of Douglas-Fir and Black Spruce in North America

\begin{tabular}{lrccc}
\hline Wood species & MC (\%) & $\begin{array}{c}\text { Specific } \\
\text { gravity }^{\mathrm{a}}\end{array}$ & $\begin{array}{c}\text { Shear parallel } \\
\text { to grain (MPa) }\end{array}$ & Remarks \\
\hline $\begin{array}{l}\text { Douglas-fir } \\
\text { (United States) }\end{array}$ & & & & $\mathrm{b}$ \\
Coast & 12 & 0.48 & 7.8 & \\
Interior west & 12 & 0.50 & 8.9 & \\
$\quad$ Interior north & 12 & 0.48 & 9.7 & \\
$\quad$ Interior south & 12 & 0.46 & 10.4 & $\mathrm{c}$ \\
Douglas-fir & 8 & 0.43 & 7.6 & \\
& 12 & & 7.0 & \\
& 16 & & 6.5 & $\mathrm{~b}$ \\
Black spruce & 12 & 0.46 & 8.5 & \\
\hline
\end{tabular}

\footnotetext{
${ }^{a}$ Based on weight when oven dry and volume at $12 \%$

${ }^{\mathrm{b}}$ Forest Products Laboratory, 1999. ${ }^{25}$

c ASTM D 2559-04. ${ }^{26}$
} MC.

In this study, ASTM D 905-03 was used in testing both the bonded and solid wood shear specimens.

\section{Bonded wood}

The effects of adhesive type and test condition on the shear strength and wood failure of Douglas-fir are shown in Table III. The shear strength after the VPD conditioning was lower than that at the dry condition for all the adhesives, including that of the solid wood specimens. These results indicate that the VPD treatment not only reduced the solid wood shear strength, but also the bonded shear strength and also reduced the amount of wood failure.

The shear strength and wood failure of black spruce, as influenced by adhesive type and test condition, are shown in Table IV. Test condition had less effect on the shear strength of black spruce, in contrast to that of Douglas-fir, which was more negatively affected by the VPD treatment, suggesting that Douglas-fir was less durable than spruce under the wet conditions.

\section{Normalized shear strength}

The shear strength values were normalized by dividing the wood-adhesive bond shear strength by the solid wood shear strength (Table V). At the dry condition, the normalized bond strengths for both Douglas-fir and black spruce for all of the adhesives were generally less than 1 , indicating that the strength of the solid wood was greater than that of the bond strength.

On the other hand, in the VPD condition, for the high-pH adhesives, the normalized strengths for both Douglas-fir and black spruce were generally greater than 1. This indicates that the short-term VPD exposure did not negatively affect the bond strength of the high-pH adhesives, confirming their 
TABLE III

Block Shear Strength and Wood Failure of Douglas-Fir ${ }^{\mathrm{a}}$

\begin{tabular}{|c|c|c|c|c|c|c|c|c|}
\hline Resin ID & Treatment & $\begin{array}{l}\text { Shear } \\
\text { strength } \\
\text { (MPa) }\end{array}$ & $\begin{array}{c}\text { Tukey's means } \\
\text { comparison } \\
\text { grouping }^{b}\end{array}$ & $\begin{array}{c}\text { Wood } \\
\text { failure (\%) }\end{array}$ & $\begin{array}{c}\text { Tukey's means } \\
\text { comparison } \\
\text { grouping }^{b}\end{array}$ & $\begin{array}{c}\text { No. of } \\
\text { specimens }\end{array}$ & $\begin{array}{c}\text { Moisture } \\
\text { content (\%) }\end{array}$ & $\begin{array}{r}\text { Density }^{\mathrm{c}} \\
\left(\mathrm{g} / \mathrm{cm}^{3}\right)\end{array}$ \\
\hline Solid wood & Dry & $13.2(1.5)$ & A1 & & - & 16 & $13.7(0.4)$ & $0.69(0.04)$ \\
\hline R-I & Dry & $11.0(2.3)$ & $\mathrm{A} 2, \mathrm{~A} 3, \mathrm{~A} 4$ & $97.4(4.1)$ & B1 & 31 & $9.9(0.4)$ & $0.66(0.02)$ \\
\hline R-II & Dry & $11.8(1.3)$ & A1, A2 & $99.8(1.0)$ & B1 & 25 & $12.0(0.4)$ & $0.66(0.02)$ \\
\hline R-III & Dry & $11.3(1.5)$ & A2, A3 & $100(0.0)$ & B1 & 23 & $12.2(0.4)$ & $0.66(0.02)$ \\
\hline R-IV & Dry & $11.6(2.0)$ & $\mathrm{A} 1, \mathrm{~A} 2, \mathrm{~A} 3$ & $100(0.0)$ & B1 & 23 & $12.2(0.4)$ & $0.66(0.02)$ \\
\hline $\mathrm{R}-\mathrm{V}$ & Dry & $11.3(0.9)$ & A2, A3 & $97.6(4.0)$ & B1 & 23 & $12.9(0.3)$ & $0.66(0.02)$ \\
\hline R-VI & Dry & 10.7 (1.3) & $\mathrm{A} 2, \mathrm{~A} 3, \mathrm{~A} 4$ & $97.7(4.0)$ & B1 & 22 & $11.8(0.3)$ & $0.66(0.02)$ \\
\hline R-VII & Dry & 10.7 (1.3) & $\mathrm{A} 2, \mathrm{~A} 3, \mathrm{~A} 4$ & $97.5(6.7)$ & B1 & 22 & $12.3(0.3)$ & $0.67(0.02)$ \\
\hline R-XI & Dry & $11.3(1.8)$ & A2, A3 & 99.1 (3.3) & B1 & 23 & $12.7(0.3)$ & $0.67(0.03)$ \\
\hline R-XII & Dry & 11.5 (1.4) & $\mathrm{A} 1, \mathrm{~A} 2, \mathrm{~A} 3$ & $91.3(15.0)$ & $\mathrm{B} 1, \mathrm{~B} 2, \mathrm{~B} 3$ & 23 & $11.5(0.4)$ & $0.66(0.02)$ \\
\hline Solid wood & VPD & 8.1 (1.7) & A5, A6 & & - & 31 & $12.9(0.5)$ & $0.69(0.04)$ \\
\hline R-I & VPD & $9.4(1.1)$ & A4, A5 & $98.6(4.3)$ & B1 & 31 & $13.0(0.6)$ & $0.66(0.02)$ \\
\hline R-II & VPD & $9.6(1.2)$ & A4, A5 & 96.7 (6.2) & B1, B2 & 24 & $13.9(0.6)$ & $0.66(0.02)$ \\
\hline R-III & VPD & 9.4 (1.3) & $\mathrm{A} 4, \mathrm{~A} 5$ & 93.9 (12.3) & $\mathrm{B} 1, \mathrm{~B} 2, \mathrm{~B} 3$ & 23 & $13.5(0.6)$ & $0.66(0.02)$ \\
\hline R-IV & VPD & $10.1(0.7)$ & $\mathrm{A} 3, \mathrm{~A} 4$ & $99.8(1.0)$ & B1 & 23 & $13.6(0.5)$ & $0.66(0.02)$ \\
\hline $\mathrm{R}-\mathrm{V}$ & VPD & $9.5(2.0)$ & $\mathrm{A} 4, \mathrm{~A} 5$ & $97.5(4.3)$ & B1 & 23 & $11.6(0.2)$ & $0.66(0.02)$ \\
\hline R-VI & VPD & $8.3(1.5)$ & A5, A6 & 85.9 (14.7) & B3, B4, B5 & 22 & $11.8(1.3)$ & $0.66(0.02)$ \\
\hline R-VII & VPD & 8.2 (1.5) & A5, A6 & 80.2 (16.1) & B4, B5 & 22 & $12.7(0.3)$ & $0.67(0.02)$ \\
\hline R-XI & VPD & $7.0(2.2)$ & A6 & $88.3(13.4)$ & $\mathrm{B} 2, \mathrm{~B} 3, \mathrm{~B} 4$ & 23 & $11.6(0.3)$ & $0.67(0.03)$ \\
\hline R-XII & VPD & $7.5(2.2)$ & A6 & $77.0(19.6)$ & B5 & 23 & $12.3(0.6)$ & $0.66(0.02)$ \\
\hline
\end{tabular}

${ }^{\text {a }}$ Means \pm standard deviations of $20+$ replicates.

b Tukey's grouping: "honestly significant difference" test was conducted for pairwise comparison, significant at 0.05 level of probability. A1, A2, etc. are groups of strength. B1, B2, etc. are groups of wood failure. If the means are in the same group, they are not significantly different.

${ }^{c}$ Based on volume and weight at $12 \% \mathrm{MC}$.

TABLE IV

Block Shear Strength and Wood Failure of Black Spruce ${ }^{\mathrm{a}}$

\begin{tabular}{|c|c|c|c|c|c|c|c|c|}
\hline Resin ID & Treatment & $\begin{array}{l}\text { Shear } \\
\text { strength } \\
(\mathrm{MPa})\end{array}$ & $\begin{array}{l}\text { Tukey's means } \\
\text { comparison } \\
\text { grouping }\end{array}$ & $\begin{array}{c}\text { Wood } \\
\text { failure }(\%)\end{array}$ & $\begin{array}{l}\text { Tukey's means } \\
\text { comparison } \\
\text { grouping }^{\mathrm{b}}\end{array}$ & $\begin{array}{c}\text { No. of } \\
\text { specimens }\end{array}$ & $\begin{array}{c}\text { Moisture } \\
\text { content }(\%)\end{array}$ & $\begin{array}{l}\text { Density }{ }^{\mathrm{c}} \\
\left(\mathrm{g} / \mathrm{cm}^{3}\right)\end{array}$ \\
\hline Solid wood & Dry & $10.8(1.2)$ & $\mathrm{C} 1, \mathrm{C} 2, \mathrm{C} 3$ & & - & 31 & $14.1(0.4)$ & $0.52(0.01)$ \\
\hline R-I & Dry & $10.2(1.3)$ & $\mathrm{C} 2, \mathrm{C} 3, \mathrm{C} 4, \mathrm{C} 5, \mathrm{C} 6$ & $95.2(9.5)$ & D1 & 36 & $10.0(1.2)$ & $0.53(0.01)$ \\
\hline R-II & Dry & $10.9(1.2)$ & C1, C2, C3 & $98.4(2.8)$ & D1 & 22 & $11.5(0.8)$ & $0.52(0.01)$ \\
\hline R-III & Dry & $10.1(1.8)$ & $\mathrm{C} 2, \mathrm{C} 3, \mathrm{C} 4, \mathrm{C} 5$ & $95.8(9.0)$ & D1 & 22 & $11.9(0.3)$ & $0.52(0.01)$ \\
\hline R-IV & Dry & $10.5(1.0)$ & $\mathrm{C} 1, \mathrm{C} 2, \mathrm{C} 3, \mathrm{C} 4, \mathrm{C} 5$ & $95.0(11.0)$ & D1 & 22 & $11.8(0.3)$ & $0.52(0.01)$ \\
\hline $\mathrm{R}-\mathrm{V}$ & Dry & $11.4(1.1)$ & $\mathrm{C} 1, \mathrm{C} 2$ & $98.8(2.2)$ & D1 & 24 & $13.4(0.3)$ & $0.53(0.01)$ \\
\hline R-VI & Dry & $10.5(1.7)$ & $\mathrm{C} 1, \mathrm{C} 2, \mathrm{C} 3, \mathrm{C} 4, \mathrm{C} 5$ & $98.8(3.6)$ & D1 & 25 & $11.3(0.2)$ & $0.54(0.01)$ \\
\hline R-VII & Dry & $9.6(1.3)$ & C3, C4, C5, C6, C7 & $95.0(3.6)$ & D1, D2 & 20 & $12.3(0.2)$ & $0.53(0.01)$ \\
\hline R-XI & Dry & $10.0(1.7)$ & $\mathrm{C} 2, \mathrm{C} 3, \mathrm{C} 4, \mathrm{C} 5, \mathrm{C} 6$ & $94.6(7.6)$ & D1, D2, D3 & 25 & $11.7(0.3)$ & $0.53(0.01)$ \\
\hline R-XII & Dry & $9.3(1.4)$ & C4, C5, C6, C7 & $84.7(15.0)$ & D3 & 24 & $11.5(0.4)$ & $0.52(0.02)$ \\
\hline Solid wood & VPD & $10.1(1.6)$ & $\mathrm{C} 2, \mathrm{C} 3, \mathrm{C} 4, \mathrm{C} 5, \mathrm{C} 6$ & & - & 31 & $13.6(0.4)$ & $0.52(0.01)$ \\
\hline R-I & VPD & $9.9(1.3)$ & C3, C4, C5, C6 & $95.2(9.5)$ & D1 & 36 & $12.7(0.7)$ & $0.53(0.01)$ \\
\hline R-II & VPD & $11.8(1.0)$ & $\mathrm{C} 1$ & $97.1(4.9)$ & D1 & 21 & $12.8(0.3)$ & $0.52(0.01)$ \\
\hline R-III & VPD & $10.7(1.4)$ & $\mathrm{C} 1, \mathrm{C} 2, \mathrm{C} 3, \mathrm{C} 4$ & $93.4(8.2)$ & D1, D2, D3 & 22 & $12.4(0.3)$ & $0.52(0.01)$ \\
\hline R-IV & VPD & $10.5(0.8)$ & $\mathrm{C} 1, \mathrm{C} 2, \mathrm{C} 3, \mathrm{C} 4, \mathrm{C} 5$ & $94.6(10.7)$ & D1, D2, D3 & 22 & $13.1(0.4)$ & $0.52(0.01)$ \\
\hline $\mathrm{R}-\mathrm{V}$ & VPD & $11.0(1.3)$ & $\mathrm{C} 1, \mathrm{C} 2, \mathrm{C} 3$ & $95.4(6.1)$ & D1 & 24 & $13.0(0.3)$ & $0.53(0.01)$ \\
\hline R-VI & VPD & $8.8(2.2)$ & C6, C7 & $92.8(6.8)$ & D1, D2, D3 & 25 & $13.1(0.4)$ & $0.54(0.01)$ \\
\hline R-VII & VPD & $10.8(1.3)$ & $\mathrm{C} 1, \mathrm{C} 2, \mathrm{C} 3$ & $93.5(5.4)$ & D1, D2, D3 & 20 & $13.1(0.2)$ & $0.53(0.01)$ \\
\hline R-XI & VPD & $9.1(1.2)$ & $\mathrm{C} 5, \mathrm{C} 6, \mathrm{C} 7$ & $85.0(14.1)$ & D2, D3 & 25 & $12.6(0.3)$ & $0.53(0.01)$ \\
\hline R-XII & VPD & $8.2(1.2)$ & C7 & $66.1(16.4)$ & D4 & 23 & $11.9(0.3)$ & $0.52(0.01)$ \\
\hline
\end{tabular}

${ }^{\text {a }}$ Means \pm standard deviations of $20+$ replicates.

b Tukey's grouping: "honestly significant difference" test was conducted for the pairwise comparison, significant at 0.05 level of probability. C1, C2, etc. are groups of strength. D1, D2, etc. are groups of wood failure. If the means are in the same group, they are not significantly different.

${ }^{\mathrm{c}}$ Based on volume and weight at $12 \% \mathrm{MC}$. 
TABLE V

Normalized Block Shear Strength for Douglas-Fir and Black Spruce Specimens

\begin{tabular}{lccc}
\hline Resin ID & Test condition & Douglas-fir & Black spruce \\
\hline Solid wood & Dry & 1.00 & 1.00 \\
R-I & Dry & 0.83 & 0.95 \\
R-II & Dry & 0.90 & 1.01 \\
R-III & Dry & 0.86 & 0.94 \\
R-IV & Dry & 0.88 & 0.97 \\
R-V & Dry & 0.86 & 1.06 \\
R-VI & Dry & 0.81 & 0.97 \\
R-VII & Dry & 0.81 & 0.89 \\
R-XI & Dry & 0.86 & 0.92 \\
R-XII & Dry & 0.87 & 0.86 \\
Solid wood & VPD & 1.00 & 1.00 \\
R-I & VPD & 1.16 & 0.97 \\
R-II & VPD & 1.18 & 1.17 \\
R-III & VPD & 1.16 & 1.06 \\
R-IV & VPD & 1.25 & 1.03 \\
R-V & VPD & 1.18 & 1.09 \\
R-VI & VPD & 1.03 & 0.87 \\
R-VII & VPD & 1.02 & 1.07 \\
R-XI & VPD & 0.86 & 0.90 \\
R-XII & VPD & 0.93 & 0.81 \\
\hline
\end{tabular}

known good durability. In addition, some penetration of the adhesive into the wood probably occurred, thus reinforcing the wood layer adjacent to the bond line against the effect of the VPD exposure. For the low-pH adhesives, the normalized shear strengths for both Douglas-fir and black spruce were predominantly less than 1 , with some values slightly greater than 1 . In combination with the wood failure results, indications are that the bond quality of the low-pH adhesives was probably impaired by the VPD treatment.

\section{Statistical analysis of block shear properties}

The ANOVA performed on the block shear properties data for the five high-pH adhesives (R-I, R-II, RIII, R-IV, and R-V) is shown in Table VI. The results indicate that wood species did not have a significant effect on block shear strength, but had a significant effect on wood failure. Adhesive had a significant influence on block shear strength, but not on wood failure. Test condition had a significant effect on both block shear strength and wood failure.

The ANOVA values for the block shear properties data for the four low-pH adhesives (R-VI, R-VII, RXI, and R-XII) are given in Table VII. Wood species did not have a significant effect on either strength or wood failure. Adhesive did not have a significant effect on block shear strength at the $95 \%$ level of probability, but had a significant effect on wood failure. Again, test condition had a significant effect on both wood failure and block shear strength. Tukey's "honestly significant difference" test was conducted for the pairwise means comparison at 0.05 level of probability, and the results are shown in Tables III and IV.

For the high-pH adhesives, the block shear strengths of the Douglas-fir specimens were in the same group in dry condition (A2) and also in the VPD condition (A4) as shown in Table II. Likewise, the wood failures were all in the same group (B1). The block shear strengths of the black spruce specimens for all the adhesives were in the same group at the dry condition (C2) and at the VPD condition (C3), except that R-II had a higher value. The wood failures of the black spruce specimens were similar at the dry and at the VDP conditions (D1). The above results suggest that the adhesives with $\mathrm{pH}$ between 10.51 and 13.11, as determined by Method 4, had similar impact on the block shear strength and wood failure regardless of wood species. The present results were consistent with the findings of Santos et al. ${ }^{14}$ that high-pH phenolic resins did not have a negative effect on shear strength.

For the low-pH adhesives, the block shear strengths of the Douglas-fir specimens were similar in the dry condition (A2 and A3 in Table III), and

TABLE VI

ANOVA of Block Shear Strength and Wood Failure of High-pH Adhesives

\begin{tabular}{|c|c|c|c|c|c|c|}
\hline Source & DF & SS & Type III SS & Mean square & $F$-value & $P>F$ \\
\hline \multicolumn{7}{|c|}{ Dependent variable: strength } \\
\hline Model & 6 & 152.17 & & 25.36 & 11.39 & $<0.0001$ \\
\hline Error & 493 & $1,097.45$ & & 2.23 & & \\
\hline Corrected total & 499 & $1,249.62$ & & & & \\
\hline Wood species & 1 & & 4.12 & 4.12 & 1.85 & 0.175 \\
\hline Adhesive & 4 & & 57.58 & 14.40 & 6.47 & $<0.0001$ \\
\hline Test condition & 1 & & 90.79 & 90.79 & 40.78 & $<0.0001$ \\
\hline \multicolumn{7}{|c|}{ Dependent variable: wood failure } \\
\hline Model & 6 & $1,179.36$ & & 196.56 & 4.23 & $<0.0001$ \\
\hline Error & 493 & $22,903.30$ & & 46.46 & & \\
\hline Corrected total & 499 & $24,082.66$ & & & & \\
\hline Wood species & 1 & & 637.97 & 637.97 & 13.73 & 0.0002 \\
\hline Adhesive & 4 & & 262.11 & 65.53 & 1.41 & 0.23 \\
\hline Test condition & 1 & & 257.87 & 257.87 & 5.55 & 0.02 \\
\hline
\end{tabular}


TABLE VII

ANOVA of Block Shear Strength and Wood Failure of Low-pH Adhesives

\begin{tabular}{|c|c|c|c|c|c|c|}
\hline Source & DF & SS & Type III SS & Mean square & $F$-value & $P>F$ \\
\hline \multicolumn{7}{|c|}{ Dependent variable: strength } \\
\hline Model & 5 & 384.58 & & 76.92 & 21.74 & $<0.0001$ \\
\hline Error & 361 & $1,277.11$ & & 3.54 & & \\
\hline Corrected total & 366 & $1,661.69$ & & & & \\
\hline Wood species & 1 & & 1.41 & 1.41 & 0.40 & 0.53 \\
\hline Adhesive & 3 & & 22.67 & 7.56 & 2.14 & 0.095 \\
\hline Test condition & 1 & & 361.20 & 361.20 & 102.10 & $<0.0001$ \\
\hline \multicolumn{7}{|c|}{ Dependent variable: wood failure } \\
\hline Model & 5 & $23,094.5$ & & $4,618.9$ & 24.54 & $<0.0001$ \\
\hline Error & 361 & $67,954.15$ & & 188.24 & & \\
\hline Corrected total & 366 & $91,048.65$ & & & & \\
\hline Wood species & 1 & & 85.52 & 85.52 & 0.45 & 0.50 \\
\hline Adhesive & 3 & & $11,421.61$ & $38,07.20$ & 20.23 & $<0.0001$ \\
\hline Test condition & 1 & & $11,717.07$ & $11,717.07$ & 62.25 & $<0.0001$ \\
\hline
\end{tabular}

also in the VPD condition (A6). However, the shear strength was much lower in the VPD condition compared with the dry condition. The wood failures were similar among the adhesives and were even comparable with those of the high-pH adhesives (i.e., all in the same group B1) at the dry condition. However, the wood failures were reduced significantly at the VPD condition. Similarly, the block shear strength and wood failure of the black spruce specimens were higher at the dry condition compared with the VPD condition.

\section{CONCLUSIONS}

Adhesive type of varying $\mathrm{pH}$ and test condition significantly affected the block shear properties (strength and wood failure) of Douglas-fir and black spruce. The high-pH adhesives (PF and PRF) performed better than the low- $\mathrm{pH}$ adhesives (MF and MUF), especially after the VPD conditioning, indicating differences in durability between these two types of adhesives. High-pH adhesives did not have a negative impact on the strength of the bonded specimens.

Because the low-pH adhesives used in this study were not very durable, it is suggested that moredurable low-pH adhesives, if available, be studied to examine their impact on bond durability and properties of the wood layer adjacent to the bond line.

The authors thank all of the project liaisons for their technical support. They specially thank Stephan Raymond, Technician at FPInnovations-Wood Products, for his assistance in specimen preparation and characterization.

\section{References}

1. Stamm, A. J. Wood and Cellulose Science; The Ronald Press Co.: New York, 1964.
2. Haygreen, J. G.; Bowyer, J. L. Forest Products and Wood Science: An Introduction, 4th ed.; Iowa State Press: Iowa, 2003.

3. Gillespie, R. H.; River, B. H. Forest Product J 1975, 25, 26.

4. Raknes, A. E. Norsk Skogindustri 1976, 30, 168, 175.

5. Raknes, A. E. Norsk Skogindustri 1981, 35, 260, 270.

6. Pizzi, A.; Vosloo, R.; Cameron, F. A.; Orovan, E. Holz Roh Werkst 1986, 44, 229.

7. Kline, G. M.; Reinhart, F. W.; Rinker, R. C.; De Lollis, N. J. Modern Plast 1947, 7, 123, 196.

8. Wangaard, F. F. Summary of Information on the Durability of Woodworking Glues. Forest Products Laboratory Report No. 1530 (Revised 1956 as: Durability of Water-Resistant Woodworking Glues); Forest Service, U.S. Department of Agriculture: Washington, DC, 1946.

9. Eickner, H. W. Durability of Glue Joints Between Blocks of Compreg and of Compreg and Wood. Forest Products Laboratory Report No. 1536; Forest Service, U.S. Department of Agriculture: Washington, DC, 1945.

10. TrusJoist. A Weyerhaeuser Business, Microllam LVL Scaffold Plank \#3030 Application Guide; Weyerhaeuser NR Company: Boise, ID, 2004.

11. Green, D. W.; Evans, J. W.; Hatfield, C. A.; Byrd, P. J. Durability of Structural Lumber Products after Exposure at $82^{\circ} \mathrm{C}$ and $80 \%$ Relative Humidity. Forest Products Laboratory Research Paper FPL-RP-631; Forest Service, U.S. Department of Agriculture: Washington, DC, 2005.

12. Blomquist, R. F. Effect of Alkalinity of Phenol- and ResorcinolResin Glues on Durability of Joints in Plywood. Forest Products Laboratory Report No. R1748 (Reaffirmed 1962); Forest Service, U.S. Department of Agriculture: Washington, DC, 1949.

13. Hse, C. Y. Forest Product J 1971, 21, 44.

14. Santos, C. B.; Pimenta, A. S.; Vital, B. R.; Barbosa, L. C. A. R Arvore Vicosa-MG 2003, 27, 551.

15. Zimmermann, T.; Richter, K.; Bordeanu, N.; Sell, J. Wood Fiber Sci 2007, 39, 221.

16. Canadian Standards Association. Evaluation of Adhesives for Structural Wood Products (Exterior Exposure). CSA Standard O112.9-10; CSA: Mississauga, ON, 2010.

17. Canadian Standards Association. Evaluation of Adhesives for Structural Wood Products (Limited Moisture Exposure). CSA Standard O112.10; CSA: Mississauga, ON, 2008.

18. Canadian Standards Association. Phenol and Phenol-Resorcinol Resin Adhesives for Wood (High-Temperature Curing). CSA Standard O112.6-M1977; CSA: Rexdale, ON, 1977.

19. American Society for Testing and Materials. Standard Test Method for Hydrogen Ion Concentration of Dry Adhesive Films. ASTM D1583-01; ASTM: West Conshohocken, PA, 2001. 
20. Canadian Standards Association. Resorcinol and PhenolResorcinol Resin Adhesives for Wood (Room- and Intermediate-Temperature Curing). CSA Standard O112.7-M1977; CSA: Rexdale, ON, 1977.

21. Zhang, Y.; Wang, X. M.; Casilla, R.; Cooper, P.; Huang, Z. E.; Wang, X. D. J Appl Polym Sci 2010, 117, 2888.

22. American Society for Testing and Materials. Standard Test Method for Strength Properties of Adhesive Bonds in Shear by Compression Loading. ASTM D905-03; ASTM: West Conshohocken, PA, 2003.

23. American Society for Testing and Materials. Standard Practice for Estimating the Percentage of Wood Failure in Adhesive Bonded Joints. ASTM D5266-99; ASTM: West Conshohocken, PA, 2005.
24. Littell, R. C.; Milliken, G. A.; Stroup, W. W.; Wolfinger, R. D. SAS System for Mixed Models; SAS Institute Inc.: Cary, NC, 1996, pp 171-228.

25. Forest Products Laboratory. Wood Handbook-Wood as an Engineering Material. General Technical Report FPL-GTR113; Forest Service, Forest Products Laboratory, U.S. Department of Agriculture: Madison, WI, 1999, 463 pp.

26. American Society for Testing and Materials. Standard Specification for Adhesives for Structural Laminated Wood Products for Use under Exterior (Wet Use) Exposure Conditions. ASTM D2559; ASTM: West Conshohocken, PA, 1997.

27. American Society for Testing and Materials. Standard Test Methods for Small Clear Specimens of Timber. ASTM D143; ASTM: West Conshohocken, PA, 1994. 